OPEN ACCESS

Edited by:

Monica Hongroe Solbakken,

University of Oslo, Norway

Reviewed by: Jorge Galindo-Villegas, Nord University, Norway David Parra,

Hipra Scientific, Spain

*Correspondence:

Zhen Xu

zhenxu@mail.hzau.edu.cn

${ }^{\dagger}$ These authors have contributed equally to this work

Specialty section:

This article was submitted to

Comparative Immunology,

a section of the journal

Frontiers in Immunology

Received: 31 May 2020

Accepted: 16 September 2020

Published: 02 October 2020

Citation:

Yu Y, Wang Q, Huang Z, Ding $L$ and Xu Z (2020) Immunoglobulins,

Mucosal Immunity and

Vaccination in Teleost Fish.

Front. Immunol. 11:567941. doi: 10.3389/fimmu.2020.567941

\section{Immunoglobulins, Mucosal Immunity and Vaccination in Teleost Fish}

\author{
Yongyao $\mathrm{Yu}^{1 \dagger}$, Qingchao Wang $^{1 \dagger}$, Zhenyu Huang ${ }^{1 \dagger}$, Liguo Ding ${ }^{1 \dagger}$ and Zhen $\mathrm{Xu}^{1,2,3^{*}}$ \\ ${ }^{1}$ Department of Aquatic Animal Medicine, College of Fisheries, Huazhong Agricultural University, Wuhan, China, ${ }^{2}$ Laboratory \\ for Marine Biology and Biotechnology, Qingdao National Laboratory for Marine Science and Technology, Qingdao, China, \\ ${ }^{3}$ Key Laboratory of Marine Biotechnology of Fujian Province, Institute of Oceanology, Fujian Agriculture and Forestry \\ University, Fuzhou, China
}

Due to direct contact with aquatic environment, mucosal surfaces of teleost fish are continuously exposed to a vast number of pathogens and also inhabited by high densities of commensal microbiota. The B cells and immunoglobulins within the teleost mucosaassociated lymphoid tissues (MALTs) play key roles in local mucosal adaptive immune responses. So far, three $\lg$ isotypes (i.e., $\operatorname{lgM}$, $\lg D$, and $\lg T / Z$ ) have been identified from the genomic sequences of different teleost fish species. Moreover, teleost lgs have been reported to elicit mammalian-like mucosal immune response in six MALTs: gut-associated lymphoid tissue (GALT), skin-associated lymphoid tissue (SALT), gill-associated lymphoid tissue (GIALT), nasal-associated lymphoid tissue (NALT), and the recently discovered buccal and pharyngeal MALTs. Critically, analogous to mammalian IgA, teleost IgT represents the most ancient $\mathrm{Ab}$ class specialized in mucosal immunity and plays indispensable roles in the clearance of mucosal pathogens and the maintenance of microbiota homeostasis. Given these, this review summarizes the current findings on teleost Igs, MALTs, and their immune responses to pathogenic infection, vaccination and commensal microbiota, with the purpose of facilitating future evaluation and rational design of fish vaccines.

Keywords: evolution, immunoglobulins, mucosal immunity, mucosa-associated lymphoid tissues, teleost

\section{INTRODUCTION}

Aquatic environments, which are inhabited by teleost fish, provide more nutrients to microbes than land ecosystems and therefore are more conducive to bacterial growth (1). Therefore, potential pathogens mostly enter the bodies of fish across their mucosal epithelial barriers including the gills, gastrointestinal system or skin lesions (2). Unlike invertebrates, teleost fish has evolved both innate and adaptive immunity to protect themselves against pathogens residing in their aquatic environment. Similar to mammals, teleost fish also produce B- and T-cells, which constitute the first adaptive immunity mechanisms in all bony vertebrates. Particularly, B-cells and immunoglobulins (Igs) in mucosal-associated lymphoid tissues (MALTs) are thought to mediate mucosal homeostasis, given that secretory Igs (sIgs; i.e., antibodies) are known to neutralize pathogens or promote their elimination in the mucosa, thereby preventing further infection (3). Recent studies have demonstrated that B-cells within the mucosal tissues, including the gills, buccal mucosa (BM), pharyngeal mucosa (PM), and olfactory organ, exhibit potent local proliferation (4-6). Additionally, 
the large commensal microbiota populations that colonize fish mucosal surfaces can be recognized by Igs (7). So far, three main Ig isotypes have been identified in teleosts including $\operatorname{IgM}, \operatorname{IgD}$, and $\operatorname{IgT} / Z(8,9)$, of which $\operatorname{IgT} / Z$ is thought to be specialized in mucosal immunity. The predominant roles of $\operatorname{IgT} / Z$ antibodies and $\operatorname{IgT}^{+} \mathrm{B}$ cells have been elucidated in six different teleost MALTs, including GALT (10), SALT (11), GIALT (4), NALT (12), and buccal (5) and pharyngeal MALT (6).

The present review aims to summarize the regulatory functions of Igs in teleost mucosal immunity. First, we will review the basic current information on the three known teleost Igs at both the gene and protein levels. Afterward, we will describe the six different MALTs in teleosts. We will then discuss teleost Ig responses to pathogens and microbiota in mucosal surfaces and finally teleost Ig responses to immunization. Altogether, the information compiled herein will provide insights into the fundamental mechanisms of Igs in fish mucosal tissues and aid in the development of novel teleost mucosal vaccines.

\section{IMMUNOGLOBULINS}

Igs are highly specialized recognition glycoproteins that can recognize a great variety of antigens from bacteria, viruses, and other disease-causing organisms and recruit other cells and molecules to destroy these pathogens (13). Igs are composed of two heavy $(\mathrm{H})$ chains and two light $(\mathrm{L})$ chains, with the exception of certain antibodies in camelids and nurse shark that lack $\mathrm{L}$ chains (14). The constant region within the heavy chain determines the effector function of a specific antibody, which in teleosts includes $\mathrm{C} \mu, \mathrm{C} \delta$, and $\mathrm{C} \tau / \mathrm{C} \zeta$, encoding $\operatorname{IgM}, \operatorname{IgD}$, and $\operatorname{IgT} /$ $\operatorname{IgZ}$, respectively $(8,9)$. Four $\mathrm{L}$ chain types have been identified in bony fish, of which Igא and Ig $\sigma$ are found in most teleost species, $\operatorname{Ig} \lambda$ has been lost in most teleost lineages during species divergence (cod, catfish, and rainbow trout are notable exceptions), and Igo-2 was also recently identified in the coelacanth (15).

In tetrapods, naive B-cells tend to produce IgM before any other isotype, but the germinal centers of secondary lymphoid tissues can induce B-cells to express a different antibody isotype via class switching when activated by antigens (16). However, class switching does not exist in any fish species including teleosts and cartilaginous fish, as there are no distinct switch regions in the gene locus (17) despite the identification of an activation-induced cytidine deaminase (AID) (18). Two forms of Igs are reported in both teleosts and tetrapods, a membranebound form of Igs, also known as the B-cell receptor (BCR), which serves as the cell's antigen receptor, and the secreted form of Igs, which is produced by terminally differentiated B-cells, plasmablasts, and plasma cells, and functions as the main effector of B-cells in adaptive immunity (19). Here, we mainly focus on the secreted teleost forms $\operatorname{IgM}, \operatorname{IgD}$, and $\operatorname{IgT} / \mathrm{Z}$.

\section{$\lg M$}

IgM is nearly universal in all jawed vertebrates, with only the exception of the African coelacanth that carries exclusively IgW $\mathrm{H}$ chain loci (20). In teleosts harbouring IgZ/T, the $\mathrm{C} \mu$ domain is not the first constant region after the VDJ domain, and additional $\mathrm{D} \tau-\mathrm{J} \tau-\mathrm{C} \tau / \zeta$ domains are located before the $\mathrm{D} \mu / \delta$-J $\mu /$ $\delta$ - $\mathrm{C} \mu-\mathrm{C} \delta$ domains in the gene locus of the teleost $\operatorname{IgH}$ chain $(8$, 9). During $\mathrm{V}(\mathrm{D}) \mathrm{J}$ rearrangement in teleosts, the upstream $\mathrm{VH}$ could merge with the aforementioned $\mathrm{D} \mu / \delta-J \mu / \delta-\mathrm{C} \mu-\mathrm{C} \delta$ domains via $\mathrm{D} \tau-\mathrm{J} \tau-\mathrm{C} \tau / \zeta$ domain deletion, which results in IgM synthesis.

Tetrameric IgM is widely accepted as the prevalent serum Ig type in most teleosts (13). Teleost IgM lacks the J chain, and its monomers are mainly associated by covalent (disulfide) bonds. Increased disulfide polymerization has been reported to correlate with a greater affinity of trout IgM to antigens, and this trout IgM was also reported to remain active for longer periods (21). Teleost serum IgM concentration may vary $(0.6-16 \mathrm{mg} / \mathrm{ml})$ depending on water temperature and quality, as well as fish species, size, stress, stimulation, and immunization (22). During parasitic infection, both the total serum IgM concentration and parasite-specific IgM binding capacity of trout were significantly increased, in addition to an increased $\operatorname{IgM}^{+} \mathrm{B}$-cell proliferation in head kidney $(5,6)$, which demonstrated the regulatory functions of IgM in teleost systemic immunity. IgM has also been shown to occur as a tetramer in the different mucus types of rainbow trout at different concentrations, including gut mucus $(\sim 0.075 \mathrm{mg} / \mathrm{ml})$, skin mucus $(\sim 0.0046 \mathrm{mg} / \mathrm{ml})$, gill mucus $(\sim 0.02 \mathrm{mg} / \mathrm{ml})$, pharyngeal mucus $(\sim 0.072 \mathrm{mg} / \mathrm{ml})$, and nasal mucus $(\sim 0.28 \mathrm{mg} /$ $\mathrm{ml})$, all of which exhibited lower IgM concentrations than serum $(\sim 2.5 \mathrm{mg} / \mathrm{ml})$. Nonetheless, IgM still comprises the largest fraction among all three Igs in all teleost mucus, and parasitespecific IgM binding in pharyngeal mucus has been shown to increase after parasitic infection. IgM has also been found to coat bacteria in different mucus types, albeit at a lower rate than IgT (4-7, 11). Moreover, IgM expression exhibits some general features in teleosts. For instance, cytoplasmic $\operatorname{IgM}$ is normally expressed earlier than surface IgM, and Ig-producing cells appear in different tissues in the following order: head kidney, spleen, and finally MALT (23). In zebrafish, ontogenic IgM expression patterns occur in the following order: surface Ig transcript [7 days post-fertilization (dpf)], IgH chain transcript in the pancreas (10 dpf), sIg transcript (13 dpf), IgH chain transcript in the head kidney (19 dpf), and detectable humoral Ig (28 dpf) $(8,24)$.

\section{$\lg D$}

Compared to the limited (i.e., normally two or three) $\mathrm{C} \delta$ domains in mammals, the number of $\mathrm{C} \delta$ domains varies widely in different fish species (25). Unlike eutherian $\delta$ chains, in which two domains are connected by a hinge, the higher number of $\mathrm{C} \delta$ domains in teleosts may provide a wider variety of structural options to synthesize more flexible $\mathrm{H}$ chain products. Moreover, $\delta$ in bony fish was found to be uniquely formed by splicing $\mathrm{C} \mu 1$ between rearranged VDJ and $\mathrm{C} \delta 1$, producing a chimeric $\mathrm{H}$ chain sequence (26). Notably, this inclusion of $\mathrm{C} \mu 1$ has been observed in almost every teleost Ig $\delta$ transcript (27). In channel catfish, membrane bound and secreted $\operatorname{IgD}$ is transcribed from two different IgH genes. Interestingly, the secreted delta form is encoded by an IgH transcript lacking a $\mathrm{V}$-region (25). A germline-recombined VDJ is present in the second gene, but the signal sequence is directly spliced to C $\delta 1$ in 
the mRNA, indicating that the secreted $\delta$ form may not perform antigen recognition functions (17).

In teleosts, IgD was found to be to co-expressed with $\operatorname{IgM}$ in rainbow trout B-cells (4); however, an $\operatorname{IgM}^{-} / \mathrm{IgD}^{+} \mathrm{B}$-cell population was also identified in channel catfish (28) and a European trout line (29). In channel catfish, $\operatorname{IgM}^{-} / \operatorname{IgD}^{+}$B-cells isolated from peripheral blood lymphocytes (PBLs) likely expand in response to certain pathogens, functioning as pattern recognition molecules. And a recent intriguing study in the trout identified a preponderant $\operatorname{IgT}^{-}$B cells, i.e. $\operatorname{IgD}^{+} \operatorname{IgM}^{-}$ cells, to secrete IgDs which were reactive to the commensal microbiota in both gut and gills but not skin (29). However, the immunoprotective role of $\mathrm{IgD}$ in teleosts remains largely unknown. Although some reports have hypothesized the role of IgD in teleost gills (26), this antibody is known to be uninvolved in specific immunity in the gills and PM of rainbow trout during parasitic infection $(4,6)$. Additionally, teleost $\operatorname{sIgD}$ can coat a subset of commensal microbiota in mucosal tissues, including the gut mucosa, gill mucosa, BM, and PM. Nonetheless, mucosal bacteria coating by sIgD occurs significantly less than sIgT coating (4-6). These results suggest that teleost sIgD may also be involved in mucosal homeostasis.

\section{IgT}

IgT acts as a mucosal-associated Ig in bony fish, similar to IgA in mammals and IgX in frogs (10). Besides the salmonids fish (8, 9, $30,31)$, IgT subclasses are also reported in other teleosts such as stickleback (Gasterosteus aculeatus) $(32,33)$ and carp (Cyprinus carpio). Differential immune responses have been observed which may vary depending on both species and the route of pathogens/vaccination used in the study. Similar results have been observed for other ig isotypes (34). In teleost B cells, the IgH $\mathrm{V}$ domain is known to rearrange either to $\mathrm{D} \tau-\mathrm{J} \tau-\mathrm{C} \tau / \zeta$ to encode a $\tau / \zeta$ chain or to $\mathrm{D} \mu / \delta$-J $\mu / \delta$-C $\mu-\mathrm{C} \delta$ to encode $\mu$ and $\delta$ chains (19). Similar to $\operatorname{IgD}$, the number of $\tau / \zeta$ domains varied in different teleost species. For instance, four domains have been identified in most analyzed species (35); three domains in stickleback (33) and Antarctic fish (36); and two domains in fugu (37). Two separate IgZ loci encoding IgZ1 and IgZ2 have been identified in zebrafish (38) and common carp (39). IgZ1 represents a typical teleost $\operatorname{IgH} \tau / \zeta$ feature, whereas the $\mathrm{C} \mu 1$ and $\mathrm{C} \zeta 4$ domains constitute a chimeric transcript of IgZ2. Moreover, very recent study has reported that multiple independent rounds of duplication and deletion of the teleost-specific antibody class IGHZ in the cyprinodontiform lineage, demonstrating the extreme volatility of IGH evolution (40).

In rainbow trout serum, IgT mainly occurs in monomeric form and is eluted at $\sim 180 \mathrm{kDa}$, as determined from standard curve analysis. Within the multiple types of mucus, a great portion of $\operatorname{IgT}$ is present in polymeric form, whereas a small portion of IgT is still present in monomeric form during elution. Unlike the tetrameric IgM which is associated by covalent (i.e., disulfide) bonds, gut polymeric IgT is composed of non-covalent associated monomeric subunits. The concentration of $\operatorname{IgT}$ in the serum of rainbow trout is $4-10 \mathrm{mg} / \mathrm{ml}$, whereas it is $\sim 7 \mu \mathrm{g} / \mathrm{ml}$, $\sim 0.31 \mu \mathrm{g} / \mathrm{ml}, \sim 1.55 \mu \mathrm{g} / \mathrm{ml}, \sim 1.7 \mu \mathrm{g} / \mathrm{ml}$, and $\sim 3.46 \mu \mathrm{g} / \mathrm{ml}$ in the gut mucus, skin mucus, gill mucus, nasal mucus, and pharyngeal mucus, respectively. It is important to note that teleost mucus possesses a much higher ratio of $\operatorname{IgT} / \operatorname{IgM}$ than serum. Moreover, mucosal microbiota is mainly coated with $\operatorname{IgT}$ in the gut, skin, gills, and olfactory organ (4-7, 10-12). Among the different mucosal tissues, it was also observed that, compared to the gills and gut, skin mucosa showed lower IgT concentrations, lower IgT titers, and a lower percentage of coated microbiota which were correlated with lower percentages of $\operatorname{IgT}^{+} \mathrm{B}$-cells in the skin of the same fish $(4,10)$. The abundance of $\operatorname{IgT}^{+} \mathrm{B}$-cells within a specific mucosal surface may be driven by its commensal microbiota, which then modulates humoral immune response potency (7).

\section{MUCOSA-ASSOCIATED LYMPHOID TISSUE (MALT)}

So far, six different MALTs (classified based on their localization in the body) have been identified in teleost fish (Figure 1), which contain diffuse MALTs (D-MALTs) but lack the organized MALTs (O-MALTs) such as Peyer's patches and tonsils that are found in mammals. These organized structures are the inductive sites for the selection of high-affinity B-cells and are

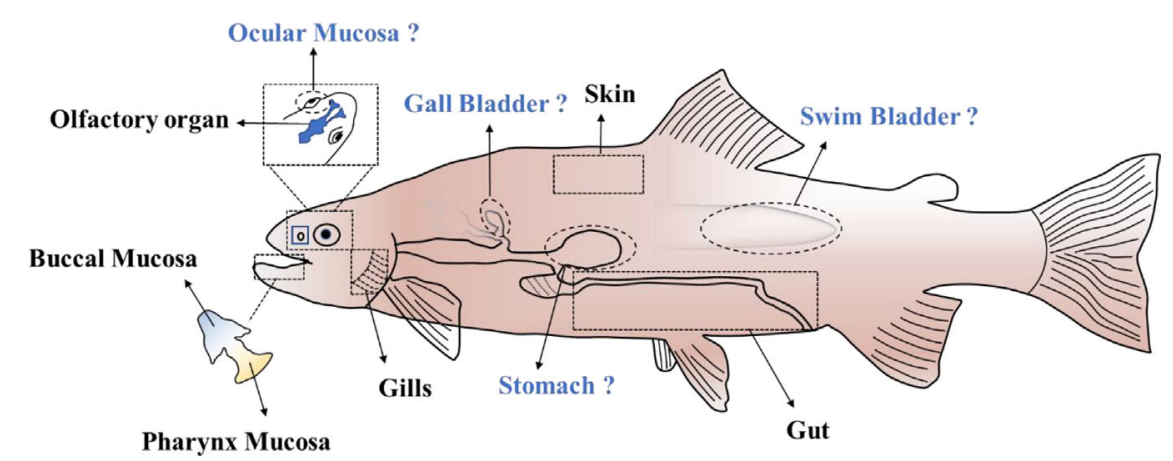

FIGURE 1 | The MALTS in teleost. "?" indicates the potential MALTs in teleost fish which remain to be clearly delineated. 
believed to facilitate antibody response maturation (41). Teleost MALTs harbor abundant myeloid and diffuse lymphoid cells, which can work together to initiate both innate and adaptive immunity to maintain mucosa homeostasis.

\section{Gut-Associated Lymphoid Tissue (GALT)}

The digestive tract is directly connected with the external environment and could be a main portal of pathogen entry in both mammals and teleost fish, among which gut is the largest part (42). As a crucial component of the mucosal immune system in teleost fish, GALT constitutes a local immune response environment for protection against pathogens. Although the gut structure varies in different teleost species, it can be generally divided into three main segments (43). The enterocytes of the first segment act as absorptive cells for dietary protein uptake. The second segment is involved in macromolecule and enterocyte uptake. The third segment is thought to have osmoregulatory functions. In addition to the digestive function of the teleost gut, studies have shown that the posterior segment of the teleost intestine contains several immune cell types $(10,17,44)$, which suggests that this section is involved in immune responses against pathogen invasion. Research on gut-associated immune responses in fish have been primarily investigated in the study of T-cell function (45); Moreover, three B-cell populations $\left(\operatorname{IgM}^{+} \operatorname{IgD}{ }^{+}, \operatorname{IgM}^{-} \operatorname{IgD}^{+}\right.$, and $\operatorname{IgT}^{+} \mathrm{B}$-cells) in the intestine of rainbow trout have been described $(10,29)$. Particularly, $\operatorname{IgM}^{+}$and $\operatorname{IgT}^{+}$B-cells have mostly been located in the lamina propria (LP), whereas some studies have shown that $\operatorname{IgT}^{+} \mathrm{B}$-cells in carp and sea bass are primarily localized in intraepithelial lymphocytes (IELs) (10). This suggests that due to the privileged population of $\operatorname{IgT}^{+} \mathrm{B}-$ cells, differential immune responses can be effortlessly generated upon infection or vaccination.

\section{Gill-Associated Lymphoid Tissue (GIALT)}

Unlike terrestrial animals that acquire oxygen from the air and possess invaginated breathing structures (i.e., lungs), aquatic organisms possess evaginated gas-exchange structures. In the case of teleost fish, four pairs of gill arches consisting of many gill filaments constitute a highly efficient way to increase contact surface to acquire oxygen from water. However, in addition to the respiratory function of the gills, they also possess osmoregulation, $\mathrm{pH}$ balance regulation, ammonia excretion, hormone regulation, and detoxification functions (46). Notably, because of their direct exposure to water, teleost gills are continuously challenged with environmental pollutants/ toxins and pathogens, both of which trigger an immune response in the teleost GIALT (47). Moreover, several studies have demonstrated that numerous innate and adaptive immune molecules or cells involved in immune-related pathways are present in teleost gills, such as Igs and antibody-secreting cells $(4,48)$. It has been noted that the $\operatorname{IgT}^{+} \mathrm{B}$-cell locus on the epithelial layer plays an essential role in the defense against pathogens (4). Moreover, unlike $\operatorname{IgM}^{+} \operatorname{IgD}^{+} \mathrm{B}$-cells, $\operatorname{IgM}^{-} \operatorname{IgD}^{+} \mathrm{B}-$ cell populations are also present in the gills of rainbow trout (29), but the function of these cells remains to be clearly characterized.

\section{Skin-Associated Lymphoid Tissue (SALT)}

The skin of teleost fish also acts as the first line of defense against invading pathogens and it contains SALT, which can elicit gutlike immune responses against pathogen infection/antigen stimulation $(11,49)$. Compared with GALT, SALT might play a key role in defense against pathogens during the earlier developmental period of the teleost fish. Recently, a model of a germ-free zebrafish embryo challenged with osmotic stress showed that the embryo skin acts as the first organ to protect the organism from bacterial infection during the early developmental period when GALT was not yet functional (50). In general, all vertebrates possess two main skin layers: the epidermis and the dermis. However, unlike mammals, teleost skin is not keratinized and therefore their epithelial cells with abundant mucus-producing cells are in direct contact with the water medium $(13,51)$. Additionally, the skin surface of teleosts generates numerous molecules including lysozymes, complements, lectins, and Igs, all of which attach to the skin mucus to protect the host (52). Skin mucus in most fish contains numerous innate immune components, which can be produced continuously to prevent the entry of pathogens to the underlying tissues. Importantly, fewer $\operatorname{IgT}^{+}$and $\operatorname{IgM}^{+}$B-cells are found in teleost SALT than in GALT. However, teleost skin B cells are dominantly located in the epidermis, and almost none of them are found in the basal dermis layer (11).

\section{Nasal-Associated Lymphoid Tissue (NALT)}

Olfaction is an essential ancient sensory system prevalent in all animals. Interestingly, the olfactory systems of teleost fish resemble those of land-based animals in terms of anatomical features (53). Given their distinctive environment, teleosts have developed different mechanisms to discriminate odors. Terrestrial vertebrates breathe and sense their environment through inhalation, whereas teleost fish actively draw water containing dissolved gases into their olfactory organs (54). Additionally, teleost olfactory organs are continually stimulated with pollutants/toxins or pathogens in the water (55). Therefore, teleost NALTs are similar to other teleost MALTs, containing diffuse lymphoid cells without organized structures, and $\operatorname{IgT}^{+}-\mathrm{B}$ cells play a crucial role in pathogenic invasion defense.

\section{Buccal Mucosa-Associated Lymphoid Tissue}

The buccal cavity, located between the gastrointestinal and respiratory tracts, is a vital mucosal surface in vertebrates. In mammals, the BM contains numerous salivary glands to produce saliva, which subsequently translocates into the salivary layer (SL). Moreover, the buccal cavity (BC) is covered with a keratinized stratified epithelium associated with the gingiva, hard palate, and outer lips and a non-keratinized stratified epithelium in other areas (56). Conversely, the BC of teleost fish is lined with abundant mucus-secreting cells that replace the function of the salivary glands in mammals to produce the mucus to coat their buccal epithelium (57). Furthermore, only non-keratinized buccal epithelia have been observed in teleost fish, which exhibit similar characteristics to those of the 
mammals. Specifically, this epithelium consists of two main layers: the stratified squamous epithelium and the $\operatorname{LP}(58,59)$. Given that aquatic environments are far more complex than air, teleost fish are subject to more stimuli. A recent study reported that fish BC also contains MALTs as in other mucosal tissues such as skin and has evolved an effective mucosal immune system to protect itself from parasite infection (5).

\section{Pharyngeal Mucosa-Associated Lymphoid Tissue}

The pharynx is connected with the digestive and respiratory tracts in vertebrates (60). In mammals, the pharyngeal cavity (PC) contains a choana which is connected with the nasal cavity (NC). However, in teleost fish, the PC (which is located between the mouth and esophagus) is a separate compartment from the NC and does not contain a choana. The PC of teleosts is coated with mucosa, and contains the stratified squamous epithelium and the LP (61). Unlike the PC of mammals, which possesses both mucus-secreting cells and mucus glands to secrete mucus into the mucus layer (62), aquatic animals lack mucus glands and instead possess numerous mucus-secreting cells in the PM. Similar to the buccal MALT, $\operatorname{IgT}^{+}$B-cells are chiefly located in the pharyngeal epithelium (PE), where their numbers increase significantly upon pathogenic invasion (6).

\section{The Potential Mucosa-Associated Lymphoid Tissues Which Might Present in Teleosts}

In addition to the six MALTs mentioned above, four potential extra MALTs might be present in the teleosts. Ocular mucosa of the teleost fish is directly exposed to the water medium. As one of the mucosa-associated lymphoid tissues in mammals, ocular mucosa plays an important role in defense against the pathogen invasion. From an evolutionary perspective, ocular mucosa in teleost fish might also have a role in protecting the individual from environmental pathogens. The stomach is another component of the digestive tract that has a potential role as MALT. Recent research has shown that IgA plays an important role in maintaining homeostasis of the stomach mucosa in mammals (63). In contrast, whether $\operatorname{IgT/IgZ~in~}$ teleosts perform a similar role as IgA in stomach remains to be demonstrated. The gallbladder is also an accessory organ of the digestive tract, and it greatly influences bile inflow into the intestine and thereby the enterohepatic circulation of bile acids. Therefore, it is closely connected to the intestine and might defense against pathogen invasion together with the intestine. Finally, the swim bladder which connects with the esophagus via the pneumatic duct is a homologous structure to the tetrapod lung (64). Its primary function is to control wholebody density and buoyancy. Recently, swim bladder-associated microbiota in rainbow trout was investigated and the result showed that Arthrobacter and Cellulosimicrobium were the major genera located in the swim bladder mucosa (65). The cross-talk between resident bacteria and host, and whether a connection exists between the swim bladder and the gut microbiota, is a highly interesting hypothesis.

\section{IMMUNOGLOBULIN RESPONSES TO PATHOGENS IN MUCOSAL SURFACES}

Fish are continuously exposed to an aquatic environment that contains abundant pathogens such as bacteria, viruses, and parasites, all of which can break through the immune barrier of the body. The mucosal immune system of fish is highly efficient and plays a critical role in resisting various pathogens, as previously reported in mammals. Many functions of mammalian IgA in mucosal secretions have been confirmed, such as preventing pathogens from adsorbing to the mucosal epithelium, mediating virus neutralization in infected cells, and promoting the death of pathogens by activating the alternative complement system pathway (66). To date, IgM, IgD, and IgT/IgZ have been identified in teleost fish and IgT/Z are the main immunoglobulin isotypes specialized in mucosal immunity $(4,7,10)$.

\section{Immunoglobulin Responses to Pathogens in the Gut}

The Igs in the teleost gut play an important role in resisting the invasion of potential pathogens through its epithelium (67). In 2010, Zhang et al. identified IgT as the most ancient known Ig specialized in mucosal immunity (10). In their report, more $\operatorname{IgT}^{+}$ B-cells were detected in the GALT of fish infected with Ceratomyxa shasta (a gut parasite) than that of control fish; however, the percentage of $\operatorname{IgM}^{+}$B-cells was not higher than that of control fish. Importantly, the authors identified parasitespecific IgM titers in serum, whereas IgT-specific responses to the parasite were confined to the gut mucus, which demonstrated that IgT might play a major role in pathogen inhibition in the fish gut. The above results suggest that teleost IgT contributes exclusively to gut mucosal immune responses, which is similar to the role of mammalian IgA, whereas IgM plays a major role in systemic immunity. In mammals, the secondary lymphoid follicles in the gut (e.g., Peyer's patches; PP) are responsible for the proliferation and enrichment of $\operatorname{IgA}^{+} \mathrm{B}$-cells (68). However, unlike mammals, teleosts lack PP, suggesting that the proliferation of IgT in the GALT of trout occurs through other pathways. In a later study on gilthead seabream (Sparus aurata), increased IgM expression in the posterior intestine was found in fish infected with Enteromyxum leei. Additionally, an increased number of $\mathrm{IgM}^{+} \mathrm{B}$-cells was also detected in the intestine of infected fish (69). Natalia et al. described that after rainbow trout were orally infected with infectious pancreatic necrosis virus (IPNV), the transcript levels of many immune-related genes significantly changed and the gene expressions of IgM and IgT were higher in the pyloric ceca than that in kidneys (70). So far, reports on Ig responses in intestinal mucosa after viral infection are still scarce. To further clarify the critical role of Igs against pathogens in the intestine of fish, additional bacterial and viral studies should be conducted.

\section{Immunoglobulin Responses to Pathogens in Gills}

Previous studies have demonstrated that gill tissues contain abundant immune cells, which are regulated by several 
immune genes and pathways (71-73). A later study examined the specific Ig responses to pathogens in fish gills (4). In this study, Ichthyophthirius multifilis (Ich) trophonts in the gills were overwhelmingly coated with IgT and slightly coated with $\operatorname{IgM}$ at 25 days post-infection (dpi), whereas parasites coated with IgD could not be detected. Moreover, a significantly increased number of $\operatorname{IgT}^{+}$B-cells in the gills could be detected in infected and survivor fish compared to control fish. In contrast, $\operatorname{IgM}^{+}$B-cell numbers did not show obvious changes. Additionally, at the protein level, IgT protein concentration also increased significantly in the gill mucus of infected and survivor fish, whereas the IgM and $\operatorname{IgD}$ protein concentrations remained unchanged. Conversely, the concentration of IgM in serum showed a significant increase (unlike IgT). Moreover, high titers of parasite-specific IgT and parasite-specific IgM were detected in gill mucus and serum, respectively. Similar results were obtained when detecting the titers of bacteria-specific IgT/ IgM in gill mucus of fish infected with Flavobacterium columnare. More details about the Ig responses in trout gills infected with F. columnare were provided in that study (74). Additionally, significant upregulation of genes encoding IgM and IgT was induced by immunization and challenge with Ich in teleost fish gills (75). Moreover, upon bath immunization, the expression of the $\operatorname{IgT}$ gene in the gills could be induced by treating Epinephelus coioides with a nervous necrosis virus vaccine (34). To elucidate the roles of Igs against different pathogens in fish gills, further studies should be conducted to provide insights into the gill responses in virus-infected fish.

\section{Immunoglobulin Responses to Pathogens in Skin}

Previous studies have found that IgT protein concentration significantly increases in skin mucus upon Ich infection and coats the surface of the invasive parasite (Ich), suggesting the critical function of IgT in skin infection resistance (11). In this study, rainbow trout infected with Ich presented a significant increase in $\operatorname{IgT}^{+} \mathrm{B}$-cells in the skin at 3 months post-infection. However, $\operatorname{IgM}^{+} \mathrm{B}$-cell numbers remained largely unchanged in infected groups. Additionally, all parasites localized within the skin epidermis were largely covered with anti-IgT antibodies. At the protein level, the IgT protein concentration in the skin mucus of infected and survivor fish was significantly higher, whereas IgM levels remained unchanged. Similar to the results in fish gut, the presence of parasite-specific Igs was discovered in skin mucus and serum. Moreover, when fish treated with mucosal vaccination were bath-challenged with pathogens, the IgM titers in serum and $\operatorname{IgT}$ responses in skin mucus were strongly induced (34). Furthermore, in Ich-infected fish, a significant upregulation of $\operatorname{IgT}$, $\operatorname{IgM}$, and $\operatorname{IgD}$ levels was observed in the skin at $24 \mathrm{~h}$ post-infection (76).

\section{Immunoglobulin Responses to Pathogens in the Olfactory Organ}

The nasal mucosa is known to inhibit and neutralize pathogens and participates in both local innate and adaptive immune responses $(12,77)$. In Ich-infected trout, parasites in the olfactory organ were mostly coated with IgT, slightly coated with IgM, and hardly coated with IgD. The nasal epithelium also produced notable $\operatorname{IgT}^{+}$B-cell accumulation when the fish survived the parasite. Moreover, in agreement with the results that nasal $\mathrm{IgT}^{+} \mathrm{B}$-cells increased in infected fish, the IgT protein concentration in the nasal mucosa of these fish was also noticeably increased, whereas $\operatorname{Ig} M$ and $\operatorname{IgD}$ protein concentrations did not show any significant changes. Contrary to the results in the nasal mucosa, the IgM concentration in the serum of infected fish significantly increased. A later study determined that parasite-specific IgT was secreted in the nasal mucosa in response to Ich infection. Additionally, Magadan et al. reported that enteric red mouth (ERM) intranasal administration resulted in a significant perturbation of the $\operatorname{IgM}(\operatorname{IgH} \mu)$ repertoire in trout spleen, and the $\operatorname{IgT}$ repertoire showed a lower diversity and higher relative IGHV2 usage compared with the controls. However, no ERM-specific IgT was detected in serum after intranasal immunization, suggesting a lower capacity to activate plasmatic B-cell differentiation or to stimulate their migration to the head kidney (78). Interestingly, Sepahi et al. reported that the percentage of $\operatorname{IgT}^{+} \mathrm{B}$ cells markedly decreased in the olfactory organ of IHNV-treated trout, whereas $\operatorname{IgM}^{+} \mathrm{B}$ cells did not change significantly (79). Therefore, to further our knowledge of Ig responses to pathogens in fish nasal mucosa, immune responses induced by bacterial and viral infections in the nasal mucosa should be further studied.

\section{Immunoglobulin Responses to Pathogens in $\mathrm{BC}$}

In tetrapod species, sIgA plays a critical role in adaptive immune responses to prevent the invasion of oral pathogens as a pivotal humoral component (80). Recently, studies of Ig responses to pathogens in the BM of fish have also been conducted (5). The highest innate immune response intensity in fish was detected at days 14 and 28 post-Ich infection, including the expression of IgM, IgT, and IgD heavy chain genes. Moreover, similar to other fish MALTs, the accumulation of $\operatorname{IgT}^{+}$B-cells could also be observed in the buccal epithelium of surviving fish and, similar to previous studies, the number of $\operatorname{IgM}^{+}$B-cells did not change significantly. In line with the increased number of $\operatorname{IgT}^{+} \mathrm{B}$-cells in the buccal epithelium, a significantly increased $\operatorname{Ig} \mathrm{T}$ protein concentration was detected in the buccal mucus of infected and surviving fish. In contrast, the concentrations of IgM and IgD did not significantly change in the buccal mucus of the infected group. However, the concentration of IgM increased significantly in the serum of infected fish. Moreover, compared to the Igs concentration of control fish, the titers of parasite-specific IgT were much higher in the buccal mucus of infected fish, as demonstrated by a pull-down assay, whereas the titers of parasite-specific IgM increased mainly in the serum. However, no parasite-specific IgD was detected in either the buccal mucus or the serum.

\section{Immunoglobulin Responses to Pathogens in PC}

B cells and Ig are present in the PM of teleost fish (6). In fish challenged with Ich for 28 days, $\operatorname{IgT}^{+} \mathrm{B}$-cells increased 
dramatically in the PE and were found to secrete IgT. In contrast, the number of $\operatorname{IgM}^{+} \mathrm{B}$-cells in the pharynx of the infected group remained at the same level as that of the controls. Moreover, the IgT concentration in the pharyngeal mucus was also obviously upregulated, whereas the protein concentrations of IgM and IgD in the pharyngeal mucus remained unchanged after Ich infection. However, in the serum, higher $\operatorname{IgM}$ and IgT but not IgD concentrations were detected in infected fish. Upon further pull-down experiments, the titers of parasite-specific IgT and IgM were tested in both pharyngeal mucus and serum. The titers of parasite-specific IgT were higher in pharyngeal mucus, whereas the titers of parasite-specific IgM were mainly detected in serum.

\section{IMMUNOGLOBULIN RESPONSES TO MICROBIOTA AT MUCOSAL SITES}

Commensal microbes are very important to overall fish healthy, some of which have been demonstrated to be involved in the protection of fish against infectious agents (81). Fish MALTs have developed a complex immune system to interact with microbiota at mucosal sites, and the relationship between them provides mutual benefits at homeostatic conditions. Maintaining the mucosal microbial homeostasis is critical for the maintenance of the mucosa and ultimately whole-body health. Thus, understanding the mechanisms by which teleosts MALTs are involved is of critical importance. In the teleost experiments described above, three Igs have been characterized in their mucosal secretions $(\operatorname{IgM}, \operatorname{IgD}, \operatorname{IgT})$, where IgT is the most ancient antibody class specialized in mucosal immunity (10). Interestingly, it has been found that the interaction between teleost Igs and microbiota via coating (Figure 2) is similar to that in mammals (80), whereas the percentage of Ig-coated bacteria varies at individual mucosa sites. This demonstrates that microbiota control at mucosal sites has emerged early in the evolution of vertebrates and is conserved. Here, we review some current studies on teleost fish Ig immune responses to microbiota.

\section{Immunoglobulin Responses to Microbiota in the Gut}

The intestinal mucosal surface interfaces of vertebrates, including teleost fish, are colonized with large and complex microbial populations. Although microbiota composition in teleost intestines is influenced by the aquatic environment or the diet, microbial content is generally maintained at approximately $10^{7}-10^{8}$ bacteria per gram, among which aerobic and facultative anaerobic organisms are dominant (17). In some cases, the teleost-gut-associated microbiota is also essential for body health, as zebrafish devoid of microbiota showed impaired innate immune functions when compared to normal fish (82). Alternatively, under the effects of a stressor, symbiotic bacteria can also turn into pathogenic bacteria, thereby causing disease or even death (83). Therefore, the role of GALT in the control of homeostasis of commensal microorganisms is crucial to support fish health $(84,85)$.

In mammals, the involvement of IgA in the coating of both beneficial bacteria and opportunists promote the preservation of microbiota homeostasis on mucosal surfaces $(84,86)$. Given that IgT appears to be a dedicated mucosal Ig in teleosts, IgT not only plays a key role in pathogen response but is also implicated in intestinal homeostasis by recognizing and coating bacterial microbiota (10). In a previous study, almost half of the microbiota present on the intestinal surface were found to be coated with IgT, whereas IgM and IgD could only bind to a small and similar percentage of bacteria $(10,29)$. As the Ig-bacteria interaction in teleosts is currently unclear, further studies are needed to shed light on the function og $\operatorname{IgT}$, IgM and IgD with respect to bacterial coating and gut homeostasis.

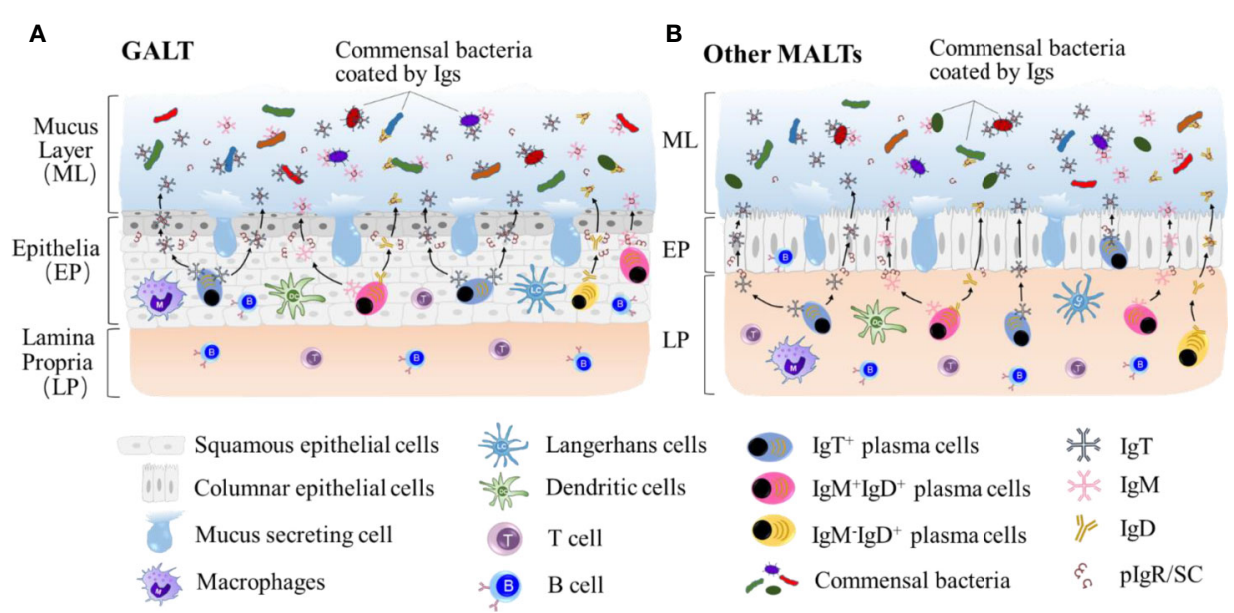

FIGURE 2 | Teleost $\lg T$, IgM and $\operatorname{lgD}$ are produced by $\lg \mathrm{T}^{+}, \operatorname{lgM}^{+} \lg \mathrm{D}^{+}$and $\lg \mathrm{M}^{-} \lg \mathrm{D}^{+} \mathrm{B}$-cells mainly located in lamina propria in $\mathrm{GALT}$ (A) and epithelial layer other MALTs, such as GIALT, SALT, NALT, PM and buccal MALT (B). Igs are transported from the epithelium into the mucus layer by the teleost plgR to maintain the homestasis of microbiota at mucosal sites. The symbiotic bacteria in the mucus is predominantly coated by slgT. 


\section{Immunoglobulin Responses to Microbiota in Gills}

Similar to the function of sIgs in mammal lungs (87), Igs in gill mucus can maintain immune homeostasis by limiting microbial antigen access to the fish body, thereby keeping the epithelial barrier's integrity and shaping the composition of the symbiotic microbiota $(4,7,74)$. One study demonstrated a large population of bacteria in the gill mucosa was predominately coated by sIgT and to a much lesser degree by $\operatorname{IgM}$ and $\operatorname{IgD}$, indicating the conserved role of a specialized mucosal Ig in vertebrates that recognize commensal bacteria on the gas-exchange surface (4). Upon IgT depletion, it was clearly observed that the percentage of IgT-coated microbiota decreased significantly and recovered when IgT was re-produced in the fish gill mucosa. Moreover, a set of microbes translocated from the mucus layer across the gill epithelium and invaded the systemic circulation in sIgTdepleted fish. IgT-seq demonstrated that IgT coats a broad but well-defined range of bacteria with both beneficial and pathogenic characteristics and microbiota composition changed significantly, which demonstrated the loss of potentially beneficial bacteria that produce short-chain fatty acids (SCFAs) and pathobiont expansion after IgT depletion. Interestingly, when the level of IgT was restored to its original state, the balance of microbiota was reestablished in the gill surfaces (7). Thus, these observations strongly imply that teleost IgT is essential to maintain microbiota homeostasis in the gills.

Additionally, Flectobacillus major, a bacterial species that dominates trout gill, can induce specific IgT secretion in the gills of healthy rainbow trout (55). It is assumed that F. major modulates Igs and then regulates the symbiotic homeostasis in the gill surface. However, its specific mechanisms still need to be determined. Thus, future studies should investigate not only the functional mechanisms by which Igs regulate the commensal microbiota and the role of IgT/IgZ in targeting specific bacteria in teleost fish gills, but also the mechanisms by which certain components of the commensal microbiota affects mucosal and systemic immunity.

\section{Immunoglobulin Responses to Microbiota in Skin}

The skin of teleosts contains a layer of live cells covered by a rich mucous layer with high densities of bacterial microbiota $(88,89)$. Under normal circumstances, the skin mucosal immune system of teleosts is in a dynamic equilibrium with symbiotic microorganisms, and skin homeostasis is critical to preserve teleost health in vertebrates. However, once the original balance is disturbed by external factors such as parasitic infection, bacterial community composition changes significantly, thereby leading to pathobiont proliferation and secondary infection (76). Thus, an understanding of the mechanism by which microbial homeostasis is maintained is necessary for the study of skin immunity in teleosts. So far, it has been demonstrated that teleost sIgs, especially sIgT, play a significant role in the control of skin symbiotic flora homeostasis. In a study on rainbow trout, IgT was found to be bound to a large fraction of skin bacteria $(\sim 38 \%)$, whereas only a small proportion $(\sim 12 \%)$ was coated with
$\operatorname{IgM}(11)$, which is consistent with the mammalian sIgA coating of skin bacterial microbiota (90). The targeting of skin microbes by mammalian sIgA plays a key role in immune exclusion (90); however, mucosal Ig can promote the colonization of certain bacteria on the skin surface (91). Therefore, considering that teleost skin is a unique mucosal surface that elicits gut-like immune responses, future research should determine whether teleost sIgT is involved in immune exclusion or assists with bacterial colonization.

\section{Immunoglobulin Responses to Microbiota in the Olfactory Organ}

The olfactory organs of vertebrates are extraordinary chemosensory structures that harbor a variety of symbiotic microorganisms in the NC (12). In mammals, nasal symbiotic bacteria play an important role in controlling immunological development via different mechanisms including inhibiting pathogen colonization on the mucosal surface and stimulating the host immune system (92). In contrast, the function of microbiota in the $\mathrm{NC}$ of teleost fish has not been determined in the olfactory organ of teleost fish; however, the bacterial community in $\mathrm{NC}$ of rainbow trout is dominated by Proteobacteria, Actinobacteria, Bacteroidetes, and Firmicutes (93), among which Proteobacteria and Firmicutes may be the most conserved taxa in the olfactory organ of vertebrates (55).

The nasal bacteria of teleosts are also anchored by sIgs, similar to those in the gul, gill and skin, to the mucus layer through a mechanism known as immune exclusion $(12,55)$. However, sIgT and sIgM in the olfactory organ coat equal proportions of microbiota in contrast to skin, gut and gills where $\operatorname{IgT}$ is specialized in coating, and IgM coats significantly lower numbers of bacteria $(10,11)$. This may be because the isotypes of Ig coating mucosal bacteria on MALTs are different due to the diversity of local microbiota (93). Alternatively, as the percentage of nasal commensal bacteria coated with both IgM and IgT is much higher than that of other mucosal sites, it is possible that the extent of Ig binding-microbiota varies in trout depending on genetic lines or ages, and some of the bacterial taxa coated by sIgM are those bacteria found initially coated by sIgT. Thus, a future Ig-seq study of the species of microbiota coated by IgT/IgZ and IgM may confirm the aforementioned possibilities.

\section{Immunoglobulin Responses to Microbiota in $\mathrm{BC}$}

The BC is covered with a critical layer of mucus that is constantly exposed to microorganisms from air, water, and food in vertebrates. Similar to humans, Proteobacteria and Actinobacteria are dominant in the BC of teleosts $(94,95)$. However, the bacterial communities differed post-infection when challenged with hematopoietic necrosis virus (IHNV); that is, the abundance of Pseudomonas significantly decreased, while the abundance of Clostridiales, Bacteroidales, and Escherichia-Shigella increased, all of which are related to human intestinal diseases (96-98). As previously described for skin sites, pathogenic infection may break the homeostasis of microbiota in the BM, facilitate the colonization of opportunistic bacteria, and then cause secondary bacterial infections in the BC (95). Thus, the 
microbial homeostasis of the teleost BM is necessary for buccal health.

It is important to point out that the BMs of vertebrates have evolved an efficient immune system to maintain homeostasis (5). Moreover, the mucosal molecular responses of fish and mammals (i.e., sIgT versus sIgA) utilize different but functionally analogous strategies to initiate a response to microbiota in the $\mathrm{BC}(5)$. Due to its constant interaction with the water environment, the homeostasis of fish BM microbiota may be prone to frequent adverse effects. Among the three teleost Igs, sIgT is also the main Ig class that binds to BMassociated bacteria, and significantly lower percentages of the microbiota are coated by sIgM and $\operatorname{sigD}$, similar to those in the gut, skin, and gills of trout $(4,5,10,11)$. So far, previous studies have demonstrated that some salivary sIgA predominantly coating commensal bacteria, such as Streptococcus mutans, Actinobacillus actinomycetemcomitans, and Porphyromonas gingivalis, are associated with mammalian buccal diseases $(99,100)$. However, the type of buccal microbiota species coated by $\operatorname{IgT/IgZ,~IgM,~and~IgD~is~still~}$ unknown, which is critical to gain insights into the role of Igs in the homeostasis of the BM in teleosts.

\section{Immunoglobulin Responses to Microbiota in PC}

The PM, as well as the ML covering the teleost PC, contains DMALT with abundant symbiotic bacteria, but without the tonsils found in mammals $(6,101)$. Microbial community compositions were analyzed via $16 \mathrm{~S}$ rRNA sequencing, and it was found that Proteobacteria and Actinobacteria were dominant in the pharynx of naive fish (95). However, although many studies have demonstrated the role of pharyngeal sIgA in pathogen elimination in vertebrates, limited studies have elucidated the interaction between mucosal Igs and PM microbiota. Our previous study on rainbow trout showed that pharyngeal Igs occur in response to commensal bacteria in PC, demonstrating that pharyngeal IgT coated a large population of bacteria while $\operatorname{IgM}$ and IgD do so to a lesser degree. Moreover, the study showed that sIgT is generated by $\operatorname{IgT}^{+} \mathrm{B}$-cells located in the PM, transferred by pIgR secreted by pIgR-expressing epithelium cells onto the pharyngeal surface, and finally binds to the microbiota (6). This fascinating similarity of IgT microbiota targeting in different MALTs may corroborate the notion that teleost MALTs form an interactive network structure and communicate with each other $(4,5,10,11)$.

\section{IMMUNOGLOBULIN RESPONSES FOLLOWING MUCOSAL IMMUNIZATION}

Compared to systemic immunization, mucosal immunization efficiently induces a local mucosal immune response (102), which can induce "frontline immunity" with local Igs production in the MALT, neutralizing pathogens and finally preventing infection (103). Additionally, mucosal vaccines are superior to systemic vaccines from a production and regulatory standpoint (104). Mucosal immunization is simple and suitable for farmed fish immunization. Additionally, immunization via injection inflicts minor trauma on the body through which pathogens may easily break through and induce an inflammatory response. In contrast, mucosal immunization does not have this potential drawback. Therefore, understanding the Igs response in teleosts following mucosal immunization will be helpful for the design and development of novel fish vaccines.

\section{Immunoglobulin Responses Following Oral Immunization}

In mammals, sIgA plays an important role in humoral immunity, which participates in adaptive immune responses to inhibit oral pathogens (80); recently, the BM of fish was proven to be a type of MALT (5). However, compared to oral immunization in mammals, oral vaccination methods in fish are still in development. Many new attempts to develop new fish immunization strategies such as the use of pathogen-coding DNA and pathogen recombinant proteins have established the basis for the potential development of oral immunization in the future (105-107). After orally treating trout with an alginateencapsulated antigen (i.e., oral vaccination), increased numbers of $\operatorname{IgT}^{+}$and $\operatorname{IgM}^{+}$B-cell were observed in the pyloric caeca, which correlated with an increased expression of IgT and IgM in the same area (108). Later on, Iván et al. demonstrated that high levels of specific IgM antibodies could be detected in fish serum when oral immunizations were administered (109). Importantly, it has been proved that recombinant tumor necrosis factor a (rTNFa) could significantly improve a commercial sea bass oral vaccine against $V$. anguillarum. And during the response, gut IgT transcripts were detected to increase (110). Overall, future studies should characterize Ig responses following oral immunization in more detail.

\section{Immunoglobulin Responses Following Immersion Immunization}

Immersion immunization is considered to be the simplest and most practical method of vaccination in aquaculture. Amend and Fender first described the method of immersion immunization in small fish, and they found that when the fish were exposed to a bovine serum albumin (BSA) solution with hyperosmotic treatment, the BSA would penetrate the juvenile trout blood, highlighting the effectiveness of immersion immunization (111). Although abundant studies on immersion immunization have been reported in different fish species, the involvement of Ig responses is relatively limited. In one study, after the fish were immersion-vaccinated with a Danish strain of Y. ruckeri serotype O1, biotype 2, the concentration of $Y$. ruckeri -specific IgM hardly changed compared to that of unvaccinated fish. However, after 3 weeks of exposure to live bacteria, the antibody level in vaccinated fish increased significantly (112). Similarly, another study also detected significantly increased IgM antibody levels in

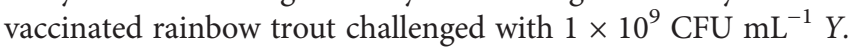
ruckeri bacterin for $1 \mathrm{~h}$ (113). Moreover, the titers of bacteriaspecific antibody in rainbow trout increased when immersion vaccinated with a $2.0 \times 10^{8} \mathrm{CFU} \mathrm{mL}^{-1}$ live F. psychrophilum suspension (114). These results suggest that immersion immunization can induce the adaptive immune response to 
protect the body. Additionally, upregulated mRNA expression of IgM and pIgR could be detected in vaccinated fish after $V$. anguillarum bacterin exposure and the pIgR expression levels were higher in some mucosal tissues (gills, skin, and hindgut) (115). Importantly, the delivery of live attenuated vaccines can improve the immune ability of fish (116). For instance, after fish fry were bath vaccinated with a live $F$. columnare vaccine, the survival rate of channel catfish (Ictalurus punctatus) increased between $57 \%$ and 94\% (117). Moreover, another study reported that zebrafish vaccinated with live attenuated Vibrio anguillarum possessed more strong mucosal immune responses (118). However, despite these observations, further studies on teleost $\operatorname{Ig} \mathrm{T} / \mathrm{IgZ}$ response and IgM and $\operatorname{IgD}$ response in fish lacking IgT following immersion immunization are still needed.

\section{Immunoglobulin Responses Following Anal Immunization}

The presentation of M-like cells in the intestine suggest that antigens could be uptaken (119), thereby inducing strong immunity in the infected or vaccinated fish. A recent study showed that, compared with oral vaccination, single-dose anal bacterin intubation following bath challenge with Y. ruckeri rendered a high survival rate in teleost fish, suggesting that immunizing antigens might have been destroyed in the stomach of the oral vaccination group. However, in the same study, no significant differences in the IgM antibody levels were detected in the plasma of the two vaccination groups at any of the sampling time points (120). A later study also demonstrated that there were no significant differences in IgM levels of anallyintubated fish, yet the expression of $\operatorname{sgD}$ and $\operatorname{IgT}$ were upregulated in both the intestines of fish immunized via anal intubation and in the gills of fish immunized by immersion (121). Recently, the anal administration of thymus-independent (TI) antigens without additional adjuvants was investigated in rainbow trout. An efficient B-cell response was induced, which facilitated the production of specific $\operatorname{IgM}$ in serum and the differentiation of antigen-specific ASCs (122).

\section{Immunoglobulin Responses Following Nasal Immunization}

Compared with other vaccination types, nasal vaccination, which is an accessible method to control infectious diseases (123), has the advantages of using a needle-free delivery system and a lower dosage of antigen to elicit an immune response. Nasal vaccines are widely used in many animals such as cats, dogs, and cattle. Nasal vaccination in mammals induces IgA-specific responses in O-NALT and D-NALT (124). Recently, the discovery of NALT in rainbow trout prompted studies concerning nasal vaccines for use in aquaculture (12). Thereafter, it was found that nasal vaccination can effectively protect fish against viral and bacterial pathogens (125). Furthermore, the nasal vaccinated group with live attenuated IHNV could significantly reduce mortalities of the trout after the IHNV infection, whereas nasal vaccinated group with formalin killed Y. ruckeri appear to fully protect fish against enteric red mouth (ERM) disease (126). Moreover, nasal vaccination with ERM bacterin also generated different IgM and IgT repertoire dynamics at systemic and mucosal levels and induced striking $\operatorname{IgT}$ responses in the spleen of rainbow trout (78).

\section{CONCLUDING REMARKS}

This review sought to gather recent advances that have shed some light on the immune responses of Igs in teleost fish to microorganisms or immunization, including mucosal pathogens, vaccines and microbiota. Teleost sIgM, sIgT, and $\operatorname{sgD}$ coexist at all mucosal sites, including the gut, gills, olfactory organ, skin, BC, and PC. During pathogenic infection, specific sIgT can be locally produced in mucosal secretions, and mucosal sensitivity increases in IgT-depleted fish, while large quantities of specific sIgM are generated in the serum. These findings suggest that the IgTmediated immune response is crucial in all mucosal sites, whereas IgM responses are typically systemic in all teleosts and also functional in mucosal sites of teleosts which lack $\operatorname{IgT} / Z(7,77)$. Considering that IgM has the highest protein concentration among teleost Igs on mucosal surfaces and that the specific IgM also can be induced in the mucosal surfaces by parasites as in the serum, it is worth investigating whether sIgM has an auxiliary effect on sIgT to eliminate pathogens at mucosal sites. Additionally, mucosal responses of Igs in fish, mainly trout, have been demonstrated after parasitic and bacterial infection (4, $5,10,11,74,77)$, but fish mucosal responses after infection by other pathogens such as virus or fungi are still unclear. In vertebrates, the common mucosal immune system (CMIS), which means that antigens administration induces humoral immune responses not only at the mucosal site of antigen application but also in other external mucosal tissues due to the dissemination of antigen-sensitized cells, is vitally important. Specifically, mammalian has been found to produce specific IgA or IgM responses in other MALTs upon stimulation of one mucosal site (127); however, data on the CMIS in teleosts remains currently limited. Therefore, our current understanding of the mechanisms underlying teleost Ig responses at mucosal sites remains nascent. Especially, the humoral immune responses in teleosts which lack IgT/Z remain much unknown. Future studies need to consider the role of $\operatorname{IgT}$, $\operatorname{IgM}$, and $\operatorname{IgD}$ in mucosal immunity to different pathogens by infection or immunization and explore the CMIS in teleosts, which will contribute to the development of fish vaccines.

Another very important point is that the mucosal microbiota is predominantly coated by teleost IgT at mucosal sites. IgT depletion induces a profound dysbiosis, the expansion of pathobionts, tissue damage, the translocation of mucosal bacteria, and inflammation. These findings demonstrate the previously unrecognized ability of IgT in immune exclusion to protect the mucosa from microbiota (7). However, information on the role of teleost sIgT in bacterial colonization remains scarce. Understanding how sIgT coating of bacteria mediates bacterial colonization under homeostatic conditions may improve the efficiency of aquatic probiotics. Moreover, it is worth noting that teleost IgM can bind a subset of microbiota, especially in the 
teleost olfactory organ, and the percentage of IgM-coating bacteria in fish is notably higher than that in mammals $(10,12,96)$. Importantly, in fish devoid of IgT, the percentage of microbiota coated by IgM is significantly higher, suggesting that compensatory sIgM might then coat microbiota that was originally coated by sIgT (7). Thus, the function of sIgM in teleost commensal homeostasis has not yet been determined, and future studies based on IgM depletion experiments may provide important insights into this matter. Additionally, mammalian IgA-derived antibodies are commonly polyreactive and show low-affinity to numerous microbial antigens. Although teleost mucosal $\operatorname{Ig}(\operatorname{IgT})$ has been found to target a taxonomically distinct subset of microbiota at the gill surface (7), the extent of the microbe recognition capacity of IgT as well as its mucosal-specific pathogen-binding capacity during infection are still unknown.

Overall, it seems clear that Igs in teleosts, similar to those of mammals, can defend mucosa against pathogens for elimination and interact with microbiota to maintain commensal homeostasis;

\section{REFERENCES}

1. Cossins AR, Crawford DL. Fish as models for environmental genomics. Nat Rev Genet (2005) 6:324-33. doi: 10.1038/nrg1590

2. Koppang EO, Kvellestad A, Fischer U. 5-Fish mucosal immunity: gill. Mucosal Health Aquaculture (2015) 93-133. doi: 10.1016/B978-0-12417186-2.00005-4

3. Mantis NJ. Role of B cells and antibodies in controlling bacterial pathogens. Encyclopedia Microbiol (2019) 194-200. doi: 10.1016/B978-0-12-8012383.66120-2

4. Xu Z, Takizawa F, Parra D, Gómez D, Gersdorff Jørgensen L, LaPatra SE, et al. Mucosal immunoglobulins at respiratory surfaces mark an ancient association that predates the emergence of tetrapods. Nat Commun (2016) 7:10728. doi: 10.1038/ncomms10728

5. Yu YY, Kong WG, Xu HY, Huang ZY, Zhang XT, Ding LG, et al. Convergent evolution of mucosal immune responses at the buccal cavity of teleost fish. iScience (2019) 19:821-35. doi: 10.1016/j.isci.2019.08.034

6. Kong WG, Yu YY, Dong S, Huang ZY, Ding LG, Cao JF, et al. Pharyngeal immunity in early vertebrates provides functional and evolutionary insight into mucosal homeostasis. J Immunol (2019) 203:3054-67. doi: 10.4049/ jimmunol.1900863

7. Xu Z, Takizawa F, Casadei E, Shibasaki Y, Ding Y, Sauters T, et al. Specialization of mucosal immunoglobulins in pathogen control and microbiota homeostasis occurred early in vertebrate evolution. Sci Immunol (2020) 5:3254. doi: 10.1126/sciimmunol.aay3254

8. Danilova N, Bussmann J, Jekosch K, Steiner LA. The immunoglobulin heavy-chain locus in zebrafish: identification and expression of a previously unknown isotype, immunoglobulin Z. Nat Immunol (2005) 6:295-302. doi: 10.1038/ni1166

9. Hansen JD, Landis ED, Phillips RB. Discovery of a unique Ig heavy-chain isotype (IgT) in rainbow trout: implications for a distinctive B cell developmental pathway in teleost fish. Proc Natl Acad Sci U S A (2005) 102:6919-24. doi: 10.1073/pnas.0500027102

10. Zhang YA, Salinas I, Li J, Parra D, Bjork S, Xu Z, et al. IgT, a primitive immunoglobulin class specialized in mucosal immunity. Nat Immunol (2010) 11:827-35. doi: 10.1038/ni.1913

11. Xu Z, Parra D, Gómeza D, Salinas I, Zhang YL, Jørgensen L, et al. Teleost skin, an ancient mucosal surface that elicits gut-like immune responses. Proc Natl Acad Sci U S A (2013) 110:13097-102. doi: 10.1073/pnas.1304319110

12. Tacchi L, Musharrafieh R, Larragoite ET, Crossey K, Erhardt EB, Martin SAM, et al. Nasal immunity is an ancient arm of the mucosal immune system of vertebrates. Nat Commun (2014) 5:5205. doi: 10.1038/ ncomms6205 however, many aspects of their responses remain poorly understood. Thus, the inner mechanisms of Igs regulating both the pathogenic clearance and commensal homeostasis should be determined in the future research.

\section{AUTHOR CONTRIBUTIONS}

All authors contributed to the article and approved the submitted version.

\section{FUNDING}

This work was supported by grants from the National Natural Science Foundation of China (U1905204, 31873045) and the Key Laboratory of Marine Biotechnology of Fujian Province (2020MB03).

13. Salinas I, Zhang YA, Sunyer JO. Mucosal immunoglobulins and B cells of teleost fish. Dev Comp Immunol (2011) 35:1346-65. doi: 10.1016/ j.dci.2011.11.009

14. Conrath KE, Wernery U, Muyldermans S, Nguyena VK. Emergence and evolution of functional heavy-chain antibodies in Camelidae. Dev Comp Immunol (2003) 27:87-103. doi: 10.1016/S0145-305X(02)00071-X

15. Saha NR, Ota T, Litman GW, Hansen J, Parra Z, Hsu E, et al. Genome complexity in the coelacanth is reflected in its adaptive immune system. J Exp Zool B Mol Dev Evol (2014) 322:438-63. doi: 10.1002/jez.b.22558

16. Roco J, Mesin L, Binder S, Nefzger C, Gonzalez-Figueroa1 P, Canete1 P, et al. Class-switch recombination occurs infrequently in germinal centers. Immunity (2019) 51:337-50. doi: 10.1016/j.immuni.2019.07.001

17. Parra D, Korytar T, Takizawa F, Sunyer J. B cells and their role in the teleost gut. Dev Comp Immunol (2016) 64:150-66. doi: 10.1016/j.dci.2016.03.013

18. Zhao Y, Pan-Hammarstrom Q, Zhao Z, Hammarstrom L. Identification of the activation-induced cytidine deaminase gene from zebrafish: an evolutionary analysis. Dev Comp Immunol (2005) 29:61-71. doi: 10.1016/j.dci.2004.05.005

19. Mashoof S, Criscitiello MF. Fish Immunoglobulins. Biology (2016) 5:1-23. doi: 10.3390/biology5040045

20. Amemiya C, Alföldi J, Lee A, Fan S, Philippe H, MacCallum I, et al. The African coelacanth genome provides insights into tetrapod evolution. Nature (2013) 496:311-6. doi: 10.1038/nature12027

21. Ye J, Bromage ES, Kaattari SL. The strength of B cell interaction with antigen determines the degree of IgM polymerization. J Immunol (2010) 184:844-50. doi: 10.4049/jimmunol.0902364

22. Solem ST, Stenvik J. Antibody repertoire development in teleosts-a review with emphasis on salmonids and Gadus morhua L. Dev Comp Immunol (2006) 30:57-76. doi: 10.1016/j.dci.2005.06.007

23. Rombout JH, Huttenhuis HB, Picchietti S, Scapigliati G. Phylogeny and ontogeny of fish leucocytes. Fish Shellfish Immunol (2005) 19:441-55. doi: 10.1016/j.fsi.2005.03.007

24. Lam SH, Chua HL, Gong Z, Lam TJ, Sin YM. Development and maturation of the immune system in zebrafish, Danio rerio: a gene expression profiling, in situ hybridization and immunological study. Dev Comp Immunol (2004) 28:9-28. doi: 10.1016/s0145-305x(03)00103-4

25. Edholm ES, Bengten E, Wilson M. Insights into the function of IgD. Dev Comp Immunol (2011) 35:1309e1316. doi: 10.1016/j.dci.2011.03.002

26. Bengtén E, Quiniou S, Hikima J, Waldbieser G, Warr GW, Miller NW, et al. Structure of the catfish IGH locus: analysis of the region including the single functional IGHM gene. Immunogenetics (2006) 58:831-44. doi: 10.1007/ s00251-006-0139-9

27. Srisapoome P, Ohira T, Hirono I, Aoki T. Genes of the constant regions of functional immunoglobulin heavy chain of Japanese flounder, Paralichthys 
olivaceus. Immunogenetics (2004) 56:292-300. doi: 10.1007/s00251-0040689-7

28. Edholm ES, Bengtén E, Stafford JL, Sahoo M, Taylor EB, Miller NW, et al. Identification of two $\operatorname{IgD}^{+} \mathrm{B}$ cell populations in channel catfish, Ictalurus punctatus. J Immunol (2010) 185:4082-94. doi: 10.4049/jimmunol.1000631

29. Perdiguero P, Martín-Martín A, Benedicenti O, Díaz-Rosales P, Morel E, Muñoz-Atienza E, et al. Teleost $\operatorname{IgD}^{+} \operatorname{IgM}^{-}$B Cells Mount Clonally Expanded and Mildly Mutated Intestinal IgD Responses in the Absence of Lymphoid Follicles. Cell Rep (2019) 29:4223-35. doi: 10.1016/j.celrep.2019.11.101

30. Yasuike M, de Boer J, von Schalburg KR, Cooper GA, McKinnel L, Messmer A, et al. Evolution of duplicated IgH loci in Atlantic salmon, Salmo salar. BMC Genomics (2010) 11:486. doi: 10.1186/1471-2164-11-486

31. Zhang N, Zhang XJ, Chen DD, Oriol Sunyer J, Zhang YA. Molecular characterization and expression analysis of three subclasses of IgT in rainbow trout (Oncorhynchus mykiss). Dev Comp Immunol (2017) 70:94105. doi: 10.1016/j.dci.2017.01.001

32. Bao Y, Wang T, Guo Y, Zhao Z, Li N, Zhao Y. The immunoglobulin gene loci in the teleost Gasterosteus aculeatus. Fish Shellfish Immunol (2010) 28 (1):40-8. doi: 10.1016/j.fsi.2009.09.014

33. Gambón-Deza F, Sánchez-Espinel C, Magadán-Mompó S. Presence of an unique IgT on the IGH locus in three-spined stickleback fish (Gasterosteus aculeatus) and the very recent generation of a repertoire of VH genes. Dev Comp Immunol (2010) 34(2):114-22. doi: 10.1016/j.dci.2009.08.011

34. Piazzon MC, Galindo-Villegas J, Pereiro P, Estensoro I, Calduch-Giner JA, Gómez-Casado E, et al. Differential Modulation of IgT and IgM upon Parasitic, Bacterial, Viral, and Dietary Challenges in a Perciform Fish. Front Immunol (2016) 7:637. doi: 10.3389/fimmu.2016.00637

35. Fillatreau S, Six A, Magadan S, Castro R, Sunyer JO, Boudinot P. The astonishing diversity of Ig classes and B cell repertoires in teleost fish. Front Immunol (2013) 4:28. doi: 10.3389/fimmu.2013.00028

36. Giacomelli S, Buonocore F, Albanese F, Scapigliati G, Gerdol M, Oreste U, et al. New insights into evolution of IgT genes coming from Antarctic teleosts. Mar Genomics (2015) 24:55-68. doi: 10.1016/j.margen.2015.06.009

37. Savan R, Aman A, Sato K, Yamaguchi R, Sakai M. Discovery of a new class of immunoglobulin heavy chain from fugu. Eur. J Immunol (2005) 35:3320-31. doi: 10.1002/eji.200535248

38. Hu YL, Xiang LX, Shao JZ. Identification and characterization of a novel immunoglobulin $\mathrm{Z}$ isotype in zebrafish: Implications for a distinct B cell receptor in lower vertebrates. Mol Immunol (2010) 47:738-46. doi: 10.1016/ j.molimm.2009.10.010

39. Ryo S, Wijdeven RH, Tyagi A, Hermsen T, Kono T, Karunasagar I, et al. Common carp have two subclasses of bonyfish specific antibody IgZ showing differential expression in response to infection. Dev Comp Immunol (2010) 34:1183-90. doi: 10.1016/j.dci.2010.06.01

40. Bradshaw WJ, Valenzano DR. Extreme genomic volatility characterizes the evolution of the immunoglobulin heavy chain locus in cyprinodontiform fishes. Proc R Soc B (2020) 287:20200489. doi: 10.1098/rspb.2020.0489

41. Salinas I. The Mucosal Immune System of Teleost Fish. Biology (2015) 4:525-39. doi: 10.3390/biology4030525

42. Arena ET, Campbell-Valois FX, Tinevez JY, Nigro G, Sachse M, MoyaNilges $\mathrm{M}$, et al. Bioimage analysis of Shigella infection reveals targeting of colonic crypts. Proc Natl Acad Sci U S A (2015) 112:3282-90. doi: 10.1073/ pnas. 1509091112

43. Rombout JH, Abelli L, Picchietti S, Scapigliati G, Kiron V. Teleost intestinal immunology. Fish Shellfish Immunol (2011) 31:616-26. doi: 10.1016/ j.fsi.2010.09.001

44. Tafalla C, Leal E, Yamaguchi T, Fischer U. T cell immunity in the teleost digestive tract. Dev Comp Immunol (2016) 64:167-77. doi: 10.1016/ j.dci.2016.02.019

45. Rombout JH, Yang G, Kiron V. Adaptive immune responses at mucosal surfaces of teleost fish. Fish Shellfish Immunol (2014) 40:634-43. doi: 10.1016/j.fsi.2014.08.020

46. Maina JN. Structure, function and evolution of the gas exchangers: comparative perspectives. J Anat (2002) 201:281-304. doi: 10.1046/j.14697580.2002 .00099

47. Gómez D, Bartholomew J, Sunyer JO. Biology and mucosal immunity to myxozoans. Dev Comp Immunol (2014) 43:243-56. doi: 10.1016/ j.dci.2013.08.014
48. Maki JL, Dickerson HW. Systemic and cutaneous mucus antibody responses of channel catfish immunized against the protozoan parasite Ichthyophthirius multifilis. Clin Diagn Lab Immunol (2003) 10:876-81. doi: $10.1128 /$ cdli.10.5.876-881.2003

49. Parra D, Reyes-Lopez FE, Tort L. Mucosal Immunity and B Cells in Teleosts: Effect of Vaccination and Stress. Front Immunol (2015) 6:354 doi: 10.3389/ fimmu.2015.00354

50. Galindo-Villegas J, Montalban-Arques A, Liarte S, de Oliveira S, PardoPastor C, Rubio-Moscardo F, et al. TRPV4-Mediated Detection of Hyposmotic Stress by Skin Keratinocytes Activates Developmental Immunity. J Immunol (2016) 196(2):738-49. doi: 10.4049/jimmunol. 1501729

51. Schempp C, Emde M, Wolfle U. Dermatology in the Darwin anniversary. Part 1: Evolution of the integument. J Dtsch Dermatol Ges (2009) 7:750-7. doi: 10.1111/j.1610-0387.2009.07193.x

52. Nigam AK, Kumari U, Mittal S, Mittal AK. Comparative analysis of innate immune parameters of the skin mucous secretions from certain freshwater teleosts, inhabiting different ecological niches. Fish Physiol Biochem (2012) 38:1245-56. doi: 10.1007/s10695-012-9613-5

53. Ache BW, Young JM. Olfaction: diverse species, conserved principles. Neuron (2005) 48:417-30. doi: 10.1016/j.neuron.2005.10.022

54. Agbesi MP, Naylor S, Perkins E, Borsuk HS, Sykes D, Maclaine JS, et al. Complex flow in the nasal region of guitarfishes. Comp Biochem Physiol A Mol Integr Physiol (2016) 193:52-63. doi: 10.1016/j.cbpa.2015.12.007

55. Sepahi A, Cordero H, Goldfine H, Esteban MÁ, Salinas I. Symbiont-derived sphingolipids modulate mucosal homeostasis and B cells in teleost fish. Sci Rep (2016) 6:39054. doi: 10.1038/srep39054

56. Squier CA, Kremer MJ. Biology of oral mucosa and esophagus. J Natl Cancer Inst Monogr (2001) 29:7-15. doi: 10.1093/oxfordjournals.jncimonographs. a003443

57. Yashpal M, Kumari U, Mittal S, Mittal AK. Histochemical characterization of glycoproteins in the buccal epithelium of the catfish, Rita rita. Acta Histochem (2007) 109:285-303. doi: 10.1016/j.acthis.2007.03.002

58. Winning TA, Townsend GC. Oral mucosal embryology and histology. Clin Dermatol (2000) 18:499-511. doi: 10.1016/s0738-081x(00)00140-1

59. Abbate $\mathrm{F}$, Germanà GP, De Carlos F, Montalbano G, Laurà R, Levanti MB, et al. The oral cavity of the adult zebrafish (Danio rerio). Anat Histol Embryol (2006) 35:299-304. doi: 10.1111/j.1439-0264.2006.00682.x

60. Graham A, Richardson J. Developmental and evolutionary origins of the pharyngeal apparatus. Evodevo (2012) 3:24. doi: 10.1186/2041-9139-3-24

61. Chatchavalvanich K, Marcos R, Poonpirom J, Thongpan A, Rocha E. Histology of the digestive tract of the freshwater stingray Himantura signifer Compagno and Roberts. Anat Embryol (2006) 211:507-18. doi: 10.1007/s00429-006-0103-3

62. Suzuki T, Sato T, Kano M, Ichikawa H. The distribution of galaninimmunoreactive nerve fibers in the rat pharynx. Neuropeptides (2013) 47:231-6. doi: 10.1016/j.npep.2013.05.001

63. Satoh-Takayama N, Kato T, Motomura Y, Kageyama T, Taguchi-AtarashiGiner N, Kinoshita-Daitoku R, et al. Bacteria-Induced Group 2 Innate Lymphoid Cells in the Stomach Provide Immune Protection through Induction of IgA. Immunity (2020) 52(4):635-49.e4. doi: 10.1016/ j.immuni.2020.03.002

64. Smith FM, Croll RP. Autonomic control of the swimbladder. Auton Neurosci (2011) 165(1):140-8. doi: 10.1016/j.autneu.2010.08.002

65. Villasante A, Ramirez C, Catalán N, Romero J. First Report of Swim BladderAssociated Microbiota in Rainbow Trout (Oncorhynchus mykiss). Microbes Environ (2017) 32(4):386-9. doi: 10.1264/jsme2.ME17071

66. Rodríguez A, Tjärnlund A, Ivanji J, Singh M, García I, Williams A, et al. Role of $\operatorname{IgA}$ in the defense against respiratory infections $\operatorname{IgA}$ deficient mice exhibited increased susceptibility to intranasal infection with Mycobacterium Bovis BCG. Vaccine (2005) 23:2565-72. doi: 10.1016/ j.vaccine.2004.11.032

67. Sommer F, Bäckhed F. The gut microbiota-masters of host development and physiology. Nat Rev Microbiol (2013) 11:227-38. doi: 10.1038/nrmicro2974

68. Cerutti A, Rescigno M. The biology of intestinal immunoglobulin A responses. Immunity (2008) 28:740-50. doi: 10.1016/j.immuni.2008.05.001

69. Estensoro I, Calduch-Giner JA, Kaushik S, Pérez-Sánchez J, Sitjà-Bobadilla A. Modulation of the IgM gene expression and IgM immunoreactive cell 
distribution by the nutritional background in gilthead sea bream (Sparus aurata) challenged with Enteromyxum leei (Myxozoa). Fish Shellfish Immunol (2012) 33:401-10. doi: 10.1016/j.fsi.2012.05.029

70. Ballesteros NA, Saint-Jean SS, Encinas PA, Perez-Prieto SI, Coll JM. Oral immunization of rainbow trout to infectious pancreatic necrosis virus (Ipnv) induces different immune gene expression profiles in head kidney and pyloric ceca. Fish Shellfish Immunol (2012) 33:174-85. doi: 10.1016/ j.fsi.2012.03.016

71. Aquilino C, Castro R, Fischer U, Tafalla C. Transcriptomic responses in rainbow trout gills upon infection with viral hemorrhagic septicemia virus (VHSV). Dev Comp Immunol (2014) 44:12-20. doi: 10.1016/j.dci.2013. 11.006

72. Pennacchi Y, Leef MJ, Crosbie PB, Nowak BF, Bridle AR. Evidence of immune and inflammatory processes in the gills of AGD-affected Atlantic salmon, Salmo salar L. Fish Shellfish Immunol (2014) 36:563-70. doi: 10.1016/j.fsi.2013.12.013

73. Shi M, Huang R, Du F, Pei Y, Liao L, Zhu Z, et al. RNA-seq profiles from grass carp tissues after reovirus (GCRV) infection based on singular and modular enrichment analyses. Mol Immunol (2014) 61:44-53. doi: 10.1016/ j.molimm.2014.05.004

74. Tongsri P, Meng K, Liu X, Wu Z, Yin G, Wang Q, et al. The predominant role of mucosal immunoglobulin IgT in the gills of rainbow trout (Oncorhynchus mykiss) after infection with Flavobacterium columnare. Fish Shellfish Immunol (2020) 99:654-62. doi: 10.1016/j.fsi.2020.01.044

75. Olsen MM, Kania PW, Heinecke RD, Skjoedt K, Rasmussen KJ, Buchmann K. Cellular and humoral factors involved in the response of rainbow trout gills to Ichthyophthirius multifiliis infections: molecular and immunohistochemical studies. Fish Shellfish Immunol (2011) 30:859-69. doi: 10.1016/j.fsi. 2011.01.010

76. Zhang XT, Ding LG, Yu YY, Kong WG, Yin YM, Huang ZY, et al. The change of teleost skin commensal Microbiota is associated with skin mucosal transcriptomic responses during parasitic infection by Ichthyophthirius multifillis. Front Immunol (2018) 9:2972. doi: 10.3389/fimmu.2018.02972

77. Yu YY, Kong W, Yin YX, Dong F, Huang ZY, Yin GM, et al. Mucosal immunoglobulins protect the olfactory organ of teleost fish against parasitic infection. PLoS Pathog (2018) 14:1007251. doi: 10.1371/journal.ppat.1007251

78. Magadan S, Jouneau L, Boudinot P, Salinas I. Nasal Vaccination Drives Modifications of Nasal and Systemic Antibody Repertoires in Rainbow Trout. J Immunol (2019) 203:1480-92. doi: 10.4049/jimmunol.1900157

79. Sepahi A, Kraus A, Casadei E, Johnston CA, Galindo-Villegas J, Kelly C, et al. Olfactory sensory neurons mediate ultrarapid antiviral immune responses in a TrkA-dependent manner. Proc Natl Acad Sci U S A (2019) 116(25):12428-36. doi: 10.1073/pnas.1900083116

80. Brandtzaeg P. Secretory immunity with special reference to the oral cavity. J Oral Microbiol (2013) 5:1-24. doi: 10.3402/jom.v5i0.20401

81. Galindo-Villegas J, García-Moreno D, de Oliveira S, Meseguer J, Mulero V. Regulation of immunity and disease resistance by commensal microbes and chromatin modifications during zebrafish development. Proc Natl Acad Sci U S A (2012) 109(39):E2605-14. doi: 10.1073/pnas.1209920109

82. Kanther M, Rawls JF. Host-microbe interactions in the developing zebrafish. Curr Opin Immunol (2010) 22:10-9. doi: 10.1016/j.coi.2010.01.006

83. Kelly C, Salinas I. Under Pressure: Interactions between Commensal Microbiota and the Teleost Immune System. Front Immunol (2017) 8:559. doi: 10.3389/fimmu.2017.00559

84. Bunker JJ, Bendelac A. IgA Responses to Microbiota. Immunity (2018) 49 (2):211-24. doi: 10.1016/j.immuni.2018.08.011

85. Pérez T, Balcázar JL, Ruiz-Zarzuela I, Halaihel N, Vendrell D, de Blas I, et al. Host-microbiota interactions within the fish intestinal ecosystem. Mucosal Immunol (2010) 3:355-60. doi: 10.1038/mi.2010.12

86. Palm NW, de Zoete MR, Flavell RA. Immune-microbiota interactions in health and disease. Clin Immunol (2015) 159:122-27. doi: 10.1016/ j.clim.2015.05.014

87. Robak OH, Heimesaat MM, Kruglov AA, Prepens S, Ninnemann J, Gutbier B, et al. Antibiotic treatment-induced secondary IgA deficiency enhances susceptibility to Pseudomonas aeruginosa pneumonia. J Clin Invest (2018) 128:3535-45. doi: 10.1172/JCI97065

88. Austin B. The bacterial microflora of fish. Sci World J (2002) 2:558-72. doi: $10.1100 /$ tsw.2002.137
89. Reid KM, Patel S, Robinson AJ, Bu L, Jarungsriapisit J, Moore LJ, et al. Salmonid alphavirus infection causes skin dysbiosis in Atlantic salmon (Salmo salar L.) post-smolts. PLoS One (2017) 12:e0172856. doi: 10.1371/ journal.pone.0172856

90. Metze D, Kersten A, Jurecka W, Gebhart W. Immunoglobulins coat microorganisms of skin surface: a comparative immunohistochemical and ultrastructural study of cutaneous and oral microbial symbionts. J Invest Dermatol (1991) 96:439-45. doi: 10.1111/1523-1747.ep12469908

91. Maynard CL, Elson CO, Hatton RD, Weaver CT. Reciprocal interactions of the intestinal microbiota and immune system. Nature (2012) 489:231-41. doi: 10.1038/nature11551

92. Buffie CG, Pamer EG. Microbiota-mediated colonization resistance against intestinal pathogens. Nat Rev Immunol (2013) 13(11):790-801. doi: 10.1038/ nri3535

93. Lowrey L, Woodhams DC, Tacchi L, Salinas I. Topographical Mapping of the Rainbow Trout (Oncorhynchus mykiss) Microbiome Reveals a Diverse Bacterial Community with Antifungal Properties in the Skin. Appl Environ Microbiol (2015) 81:6915-25. doi: 10.1128/AEM.01826-15

94. Contreras M, Costello EK, Hidalgo G, Magris M, Knight R, DominguezBello MG. The bacterial microbiota in the oral mucosa of rural Amerindians. Microbiology (2010) 156:3282-7. doi: 10.1099/mic.0.043174-0

95. Dong S, Ding LG, Cao JF, Liu X, Xu HY, Meng KF, et al. Viral-Infected Change of the Digestive Tract Microbiota Associated With Mucosal Immunity in Teleost Fish. Front Immunol (2019) 10:2878. doi: 10.3389/ fimmu.2019.02878

96. Xu J, Chen N, Wu Z, Song Y, Zhang Y, Wu N, et al. 5-aminosalicylic acid alters the gut bacterial microbiota in patients with ulcerative colitis. Front Microbiol (2018) 9:1274. doi: 10.3389/fmicb.2018.01274

97. Sears CL. Enterotoxigenic Bacteroides fragilis: a rogue among symbiotes. Clin Microbiol Rev (2009) 22:349-69. doi: 10.1128/CMR.00053-08

98. Ciarán P, Kelly M, Thomas J, LaMont M. Clostridium difficile infection. Ann Rev Med (1998) 49:375-90. doi: 10.1146/annurev.med.49.1.375

99. Mikuls TR, Payne JB, Reinhardt RA, Thiele GM, Maziarz E, Cannella AC, et al. Antibody responses to Porphyromonas gingivalis (P. gingivalis) in subjects with rheumatoid arthritis and periodontitis. Int Immunopharmacol (2009) 9:38-42. doi: 10.1016/j.intimp.2008.09.008

100. Nogueira RD, Alves AC, Napimoga MH, Smith DJ, Mattos-Graner RO. Characterization of salivary immunoglobulin A responses in children heavily exposed to the oral bacterium Streptococcus mutans: influence of specific antigen recognition in infection. Infect Immun (2005) 73:5675-84. doi: 10.1128/IAI.73.9.5675-5684.2005

101. Yokoyama Y, Harabuchi Y. Intranasal immunization with lipoteichoic acid and cholera toxin evokes specific pharyngeal IgA and systemic IgG responses and inhibits streptococcal adherence to pharyngeal epithelial cells in mice. Int J Pediatr Otorhinolaryngol (2002) 63:235-41. doi: 10.1016/s0165-5876 (02)00021-6

102. Neutra MR, Kozlowski PA. Mucosal vaccines: the promise and the challenge. Nat Rev Immunol (2006) 6:148-58. doi: 10.1038/nril777

103. Rose MA. Mucosal immunization in perspective. Hum Vaccin Immunother (2014) 10:2115-7. doi: 10.4161/hv.29609

104. Levine MM. Immunogenicity and efficacy of oral vaccines in developing countries: lessons from a live cholera vaccine. BMC Biol (2010) 8:129. doi: 10.1186/1741-7007-8-129

105. De las Heras AI, Rodríguez Saint-Jean S, Pérez-Prieto SI. Immunogenic and protective effects of an oral DNA vaccine against infectious pancreatic necrosis virus in fish. Fish Shellfish Immunol (2010) 28:562-70. doi: $10.1016 /$ j.fsi.2009.12.006

106. Tian JY, Yu J, Sun XQ. Chitosan microspheres as candidate plasmid vaccine carrier for oral immunisation of Japanese flounder (Paralichthys olivaceus). Vet Immunol Immunopathol (2008) 126(3-4):220-9. doi: 10.1016/ j.vetimm.2008.07.002

107. Gomez-Casado E, Estepa A, Coll JM. A comparative review on Europeanfarmed finfish RNA viruses and their vaccines. Vaccine (2011) 29:2657-71. doi: 10.1016/j.vaccine.2011.01.097

108. Ballesteros NA, Castro R, Abos B, Rodríguez Saint-Jean SS, Pérez-Prieto SI, Tafalla C, et al. The pyloric caeca area is a major site for $\operatorname{IgM}(+)$ and $\operatorname{IgT}(+)$ B cell recruitment in response to oral vaccination in rainbow trout. PLoS One (2013) 8:e66118. doi: 10.1371/journal.pone.0066118 
109. Tobar I, Arancibia S, Torres C, Vera V, Soto P, Carrasco C, et al. Successive Oral Immunizations Against Piscirickettsia Salmonis and Infectious Salmon Anemia Virus are Required to Maintain a Long-Term Protection in Farmed Salmonids. Front Immunol (2015) 6:244. doi: 10.3389/fimmu.2015.00244

110. Galindo-Villegas J, Mulero I, García-Alcazar A, Muñoz I, Peñalvez-Mellado $\mathrm{M}$, Streitenberger S, et al. Recombinant TNF $\alpha$ as oral vaccine adjuvant protects European sea bass against vibriosis: insights into the role of the CCL25/CCR9 axis. Fish Shellfish Immunol (2013) 35(4):1260-71. doi: 10.1016/j.fsi.2013.07.046

111. Amend DF, Fender DC. Uptake of bovine serum albumin by rainbow trout from hypersmotic solutions: a model for vaccinating fish. Science (1976) 192:793-4. doi: 10.1126/science.1265480

112. Jaafar RM, Al-Jubury A, Chettri JK, Dalsgaard I, Kania PW, Buchmann K. Secondary immune response of rainbow trout following repeated immersion vaccination. J Fish Dis (2018) 41:117-23. doi: 10.1111/jfd.12682

113. Raida MK, Nylén J, Holten-Andersen L, Buchmann K. Association between plasma antibody response and protection in rainbow trout Oncorhynchus mykiss immersion vaccinated against Yersinia ruckeri. PLoS One (2011) 6: e18832. doi: 10.1371/journal.pone.0018832

114. Lorenzen E, Brudeseth BE, Wiklund T, Lorenzen N. Immersion exposure of rainbow trout (Oncorhynchus mykiss) fry to wildtype Flavobacterium psychrophilum induces no mortality, but protects against later intraperitoneal challenge. Fish Shellfish Immunol (2010) 28:440-4. doi: 10.1016/j.fsi.2009.11.025

115. Sheng X, Qian X, Tang X, Xing J, Zhan W. Polymeric immunoglobulin receptor mediates immune excretion of mucosal IgM-antigen complexes across intestinal epithelium in flounder (Paralichthys olivaceus). Front Immunol (2018) 9:1562. doi: 10.3389/fimmu.2018.01562

116. Huising MO, Guichelaar T, Hoek C, Verburg-van Kemenade BM, Flik G, Savelkoul HF, et al. Increased efficacy of immersion vaccination in fish with hyperosmotic pretreatment. Vaccine (2003) 21:4178-93. doi: 10.1016/s0264410x(03)00497-3

117. Shoemaker CA, Klesius PH, Drennan JD, Evans JJ. Efficacy of a modified live Flavobacterium columnare vaccine in fish. Fish Shellfish Immunol (2011) 30 (1):304-8. doi: 10.1016/j.fsi.2010.11.001

118. Liu X, Wu H, Chang X, Tang Y, Liu Q, Zhang Y. Notable mucosal immune responses induced in the intestine of zebrafish (Danio rerio) bath-vaccinated with a live attenuated Vibrio anguillarum vaccine. Fish Shellfish Immunol (2014) 40:99-108. doi: 10.1016/j.fsi.2014.06.030

119. Fuglem B, Jirillo E, Bjerkås I, Kiyono H, Nochi T, Yuki Y, et al. Antigensampling cells in the salmonid intestinal epithelium. Dev Comp Immunol (2010) 34(7):768-74. doi: 10.1016/j.dci.2010.02.007
120. Villumsen KR, Neumann L, Ohtani M, Strøm HK, Raida MK. Oral and anal vaccination confers full protection against enteric redmouth disease (ERM) in rainbow trout. PLoS One (2014) 9:e93845. doi: 10.1371/journal. pone.0093845

121. Makesh M, Sudheesh PS, Cain KD. Systemic and mucosal immune response of rainbow trout to immunization with an attenuated Flavobacterium psychrophilum vaccine strain by different routes. Fish Shellfish Immunol (2015) 44:156-63. doi: 10.1016/j.fsi.2015.02.003

122. Martín-Martín A, Simón R, Abós B, Díaz-Rosales P, Tafalla C. Rainbow trout mount a robust specific immune response upon anal administration of thymus-independent antigens. Dev Comp Immunol (2020) 109:103715. doi: 10.1016/j.dci.2020.10371

123. Birkhoff M, Leitz M, Marx D. Advantages of Intranasal Vaccination and Considerations on Device Selection. Indian J Pharm Sci (2009) 71:729-31.

124. Yanagita M, Hiroi T, Kitagaki N, Hamada S, Ito HO, Shimauchi H, et al. Nasopharyngeal-associated lymphoreticular tissue (NALT) immunity: fimbriae-specific Th1 and Th2 cell-regulated IgA responses for the inhibition of bacterial attachment to epithelial cells and subsequent inflammatory cytokine production. J Immunol (1999) 162:3559-65.

125. LaPatra S, Kao S, Erhardt EB, Salinas I. Evaluation of dual nasal delivery of infectious hematopoietic necrosis virus and enteric red mouth vaccines in rainbow trout (Oncorhynchus mykiss). Vaccine (2015) 33:771-76. doi: $10.1016 /$ j.vaccine.2014.12.055

126. Salinas I, LaPatra SE, Erhardt EB. Nasal vaccination of young rainbow trout (Oncorhynchus mykiss) against infectious hematopoietic necrosis and enteric red mouth disease. Dev Comp Immunol (2015) 53:105-11. doi: 10.1016/ j.dci.2015.05.015

127. Brandtzaeg P, Pabst R. Let's go mucosal: communication on slippery ground. Trends Immunol (2004) 25(11):570-7. doi: 10.1016/j.it.2004.09.005. Erratum in: Trends Immunol. 2005 Jan;26(1):12.

Conflict of Interest: The authors declare that the research was conducted in the absence of any commercial or financial relationships that could be construed as a potential conflict of interest.

Copyright (c) $2020 \mathrm{Yu}$, Wang, Huang, Ding and Xu. This is an open-access article distributed under the terms of the Creative Commons Attribution License (CC BY). The use, distribution or reproduction in other forums is permitted, provided the original author(s) and the copyright owner(s) are credited and that the original publication in this journal is cited, in accordance with accepted academic practice. No use, distribution or reproduction is permitted which does not comply with these terms. 